\title{
PENGARUH PENGAWASAN TERHADAP KINERJA KARYAWAN PADA CV. HAVRACO JAYA PALEMBANG
}

\author{
Tri Darmawati *
}

\begin{abstract}
ABSTRAK
Tujuan penelitian ini untuk mengetahui pengaruh pengawasan terhadap kinerja karyawan Pada CV. Havraco Jaya Palembang. Populasi dan sampel dalam penelitian ini berjumlah 30 orang karyawan. Teknik pengumpulan data yang digunakan adalah dokumentasi dan kuisioner. Data variabel pengawasan dan kinerja dikumpulkan melalui sebaran kuisioner kepada 30 orang karyawan CV. Havraco Jaya Palembang. Teknik analisis yang digunakan dalam penelitian ini adalah regresi linier sederhana, analisis korelasi dan uji t dengan bantuan software SPSS 20.

Berdasarkan hasil pengujian yang telah dilakukan diperoleh hasil persamaan regresi linear sederhana $Y=18,975+0,745 X$ yang berarti setiap perubahan 1 (satu) unit nilai $X$ atau variabel pengawasan akan menyebabkan peningkatan nilai $Y$ atau variabel kinerja sebesar 0,745 . Selanjutnya dari hasil uji nilai $t_{\text {hitung }}$ dengan $t_{\text {tabel }}$ diperoleh hasil $t_{\text {hitung }}=3,229$ lebih besar dibandingkan dengan $t_{\text {tabel }}$ $=2,048$ pada taraf nyata 0,05 . Dengan demikian maka keputusannya adalah menolak hipotesis nol (Ho) dan menerima hipotesis alternative $(\mathrm{Ha})$ yaitu terdapat pengaruh pengawasan terhadap kinerja karyawan pada CV. Havraco Jaya Palembang. Dengan demikian dapat disimpulkan bahwa secara statistik terbukti bahwa terdapat pengaruh pengawasan terhadap kinerja karyawan pada CV. Havraco Jaya Palembang.
\end{abstract}

Kata kunci : Pengawasan dan Kinerja

\section{A. Pendahuluan}

Seorang pemimpin tentunya perlu untuk melakukan pembinaan terhadap karyawan sesuai dengan peraturan yang ada. Peraturan yang dibuat dapat membentuk sikap karyawan dalam bekerja dan menimbulkan suasana yang tertib. Sehingga pencapaian tujuan perusahaan dapat terlaksana dengan baik. Agar suatu perusahaan dapat berhasil dalam mencapai tujuan yang di tentukan, maka pengawasan memegang peranan penting dalam mengontrol kinerja karyawan. Pengawasan itu harus dilaksanakan dengan baik sehingga diharapkan sebagian besar peraturan-peraturan yang telah ditetapkan oleh organisasi dapat ditaati oleh karyawan, sehingga pekerjaan yang dilakukan akan lebih efektif. Apabila pengawasan tidak dilakukan, maka karyawan yang dulunya rajin, disiplin dan produktif akan berubah menjadi pemalas. Hal ini berdampak buruk terhadap kemajuan perusahaan, sehingga bila tidak di ambil tindakan tegas, maka dapat mengakibatkan hasil kerja yang tidak efektif.

Kinerja karyawan dalam perusahaan merupakan jawaban dari berhasil atau tidaknya tujuan organisasi yang telah ditetapkan. Apabila atasan atau manajer tidak memperhatikan kinerja karyawan maka dikhawatirkan perusahaan akan menghadapi krisis yang serius. Untuk mengatasinya atasan harus menggunakan sistem manejemen yang baik dan terarah. Salah satunya dalam hal pengawasan, seorang manejer harus mampu melakukan pengawasan secara efektif dan maksimal, agar kinerja karyawan juga akan semakin meningkat. Akan tetapi seorang karyawan akan lebih giat meningkatkan kinerjanya apabila di suatu perusahaan tempat ia bekerja mempunyai pengawasan yang baik untuk karyawan.

Berdasarkan uraian di atas dapat dirumuskan masalah yaitu: apakah terdapat pengaruh

*) Dosen Tetap Fakultas Ekonomi UPGRI Palembang 
pengawasan terhadap kinerja karyawan pada CV. Havraco Jaya Palembang. Adapun tujuan dari penelitian ini adalah untuk mengetahui pengaruh pengawasan terhadap kinerja karyawan pada CV. Havraco Jaya Palembang. Manfaat dari penelitian ini adalah untuk mengkaji kaitan pengawasan dengan kinerja karyawan di perusahaan tersebut.

\section{B. Kajian Pustaka}

1. Pengawasan

Dalam rangka mencapai tujuan suatu organisasi baik organisasi besar maupun kecil, fungsi pengawasan merupakan unsur yang penting demi kelangsungan dan pertumbuhan serta keselamatan organisasi yang bersangkutan. Pengawasan merupakan salah satu unsur dalam kegiatan adminitrasi yang dalam urutan penulisannya selalu berada di belakang. Kondisi ini sering di hubungkan dengan penempatannya sebagai bagian akhir dari keseluruhan adminitrasi dan kegiatan pengendalian atas kerjasama unit-unit dan atau sejumlah karyawan untuk mencapai tujuan perusahaan.

Menurut Sukarman (2011:111) pengawasan ialah pemeriksaan apakah sesuatu yang terjadi sesuai dengan rencana, instruksi yang di keluarkan dan prinsip-prinsip yang telah di tentukan, jadi tujuannya ialah untuk menunjukan kelemahan dan kesalahan agar supaya menjadi benar dan mencegah pengulangan kesalahan pengawasan, orang-orang dan tindakan-tindakannya.

Merchant dalam Setyowati, (2013:151-152) pengawasan dapat dirumuskan sebagai proses kegiatankegiatan untuk memastikan bahwa kegiatan-kegiatan di selesaikan sebagai telah di rencanakan dan proses mengoreksi setiap penyimpangan yang terjadi. Setiap manejer harus terlibat dalam proses pengawasan pada unit-unit kerja sehingga berfungsi sebagaimana direncanakan. Para manejer sesungguhnya tidak mungkin mengetahui apakah unit-unit mereka berkeja sebagai mana mestinya sampai mereka mengevaluasi kegiatan mana yang telah di kerjakan dan membandingkan kinerja yang sebenarnya dengan standar yang dikehendaki. Pengawasan berarti mendeterminasi apa yang telah di laksanakan, maksudnya pengevaluasian prestasi kerja dan apabila perlu menetapkan tindakantindakan korektif sehingga hasil dari pekerjaan sesuai dengan rencana. Pengawasan adalah suatu bentuk pengamatan yang umumnya dilakukan secara menyeluruh, dengan jalan mengadakan perbandingan antara kenyataan dengan yang direncanakan.

Pengawasan sebagai proses pengamatan dari pelaksanaan seluruh kegiatan organisasi untuk menjamin agar supaya semua pekerjaan yang sedang di lakukan berjalan sesuai dengan rencana yang telah di tentukan. Dari sini terlihat jelas bahwa terdapat hubungan yang sangat erat antara perencanaan dan pengawasan. Perencanaan dan pengawasan merupakan kedua belahan mata uang yang sama. Oleh karena itu pengawasan tidak dapat di laksanakan jika tidak ada perencanaan karena tidak ada pedoman bagi pengawasan. Sebaliknya rencana tanpa pengawasan akan berarti timbulnya penyimpangan-penyimpangan. atau penyelewengan yang serius tanpa ada alat untuk mencegahnya.

Melalui perencanaan yang baik dapat dibuat struktur organisasi untuk memperlancar tercapainya tujuan secara efisien, namun tidak ada jaminan bahwa kegiatan-kegiatan itu akan berlangsung sebagai mana di 
rencanakan. Oleh karenanya pengawasan itu merupakan jembatan terakhir dalam rantai fungsional kegiatan-kegiatan manajemen.

Terkait dengan pentingnya pengawasan, banyak cara yang dapat dan harus ditempuh untuk meningkatkan efisiensi kerja dalam suatu organisasi. Efisiensi dapat pula di tingkatkan melalui organisasi yang sederhana, sesuai dengan kebutuhan, kesimpangsiuran wewenang dan tanggung jawab dapat dicegah serta pendelegasian wewenang yang sistematis. efisiensi dapat pula di capai melalui sistem penggerakan yang merangsang para bawahan bekerja dengan iklas, jujur, loyal, taat. Pada saat semua sudah di laksanakan oleh manejer dengan baik, tetapi apabila manejer tidak memiliki sistem pengawasan, maka efisiensi sulit di capai. Dengan demikian jelas betapa penting fungsi pengawasan bagi efisiensi dalam pencapaian tujuan organisasi. Robbins dan Coulter dalam Setyowati (2013:153)

Milton mandell dalam Moekijat (2010:121) mempunyai anggapan bahwa Semua pekerjaan yang bersifat mengawasi pada umumnya mempunyai tugas-tugas tertentu, meskipun tugas-tugas ini secara kualitatif dan kuantitatif berbeda yang satu dengan yang lain, yang paling penting dari tugas-tugas yang dimaksud ialah :

1. Bergaul dengan bawahan.

2. Memimpin soal teknis.

3. Mengadakan koordinasi dengan pekerjaan unit-unit organisasi lainya.

4. Melatih pegawai.

5. Merencanakan perbaikanperbaikan dan metode-metode kerja dan

6. Membangun semangat kerja. Menurut Sukarman (2011:112) maksud dan tujuan pengawasan ialah mengusahakan agar perencanaan menjadi kenyataan. Oleh karena itu agar suatu sistem pengawasan lebih efektif manejer harus dapat segera melaporkan penyimpanganpenyimpangan itu dan dapat diambil tindakan. hal ini bertujuan agar pelaksanaan secara keseluruhan benar-benar dapat sesuai atau dapat mendekati apa yang direncanakan.

Selain untuk mencapai tujuan yang telah ditetapkan, pengawasan juga dapat menentukan atau mempengaruhi pelaksanaan pekerjaan yaitu sasaran. Sasaran dan tujuan didalam pengawasan hampir sama dan memang sangat erat hubungannya sebab sasaran lebih sifat dinamis sedangkan tujuan sifatnya statis yakni tujuan diukur dari hasil pekerjaan sedangkan sasaran merupakan sarana untuk mencapai tujuan tersebut. Maka dari itu tujuan pengawasan ialah sebagai berikut:

1. Untuk mengetahui jalannya pekerjaan apakah lancar atau tidak.

2. Untuk memperbaiki kesalahankesalahan yang di buat oleh pegawai dan mengusahakan pencegahan agar supaya tidak terulang kembali kesalahan yang sama atau timbulnya kesalahankesalahan yang baru.

3. Untuk mengetahui apakah penggunaan anggaran yang telah di tetapkan dalam perencanaan terarah kepada sasarannya dan sesuai dengan yang telah di tentukan.

4. Untuk mengetahui apakah pelaksanaan biaya sesuai dengan program (fase/tingkat pelaksanaan) seperti yang telah ditentukan dalam perencanaan atau tidak.

5. Untuk mengetahui apakah hasil pekerjaan sesuai dengan rencana (standar) yang telah ditetapkan. 
6. Untuk mengetahui apakan pelaksanaan kerja sesuai dengan prosedur dan kebijaksanaan yang telah di tentukan.

Menurut Terry dalam Sukarman (2011:116) mengemukakan tentang proses pengawasan sebagai berikut:

1. Tentukan standar atau dasar bagi pengawasan

2. Ukurlah pelaksanaan

3. Bandingkan pelaksanaan dengan standar dan temukanlah perbedaan jika ada.

4. Perbaiki penyimpangan dengan cara-cara tindakan yang tepat.

5. Tentukan apa yang harus dikerjakan atau di harapkan

6. Periksalah apa yang sedang di kerjakan

7. Bandingkan hasilkan dengan yang diharapkan

8. Menyetujui hasil atau tidak menyetujuinya apabila tidak menyetujuinya lakukanlah langkah-langkah perbaikan yang di perlukan.

Macam-macam pengawasan menurut terry dalam sukarman (2011:119) adalah seperti di bawah ini:

1. Pengawasan barang-barang invertaris

2. Perngawasan produksi

3. Pengawasan pemeliharaan

4. Pengawasan kualitas

5. Pengawasan jumlah barangbarang

6. Pengawasan upah/gaji

7. Pengawasan penjualan

8. Pengawasan biaya

$$
\text { Newman dalam Setyowati }
$$

(2013:155) tugas penting bagi manajer yang akan mendesain program pengawasan adalah menemukan sejumlah indikator atau peramal yang dapat diandalkan untuk tiap-tiap tujuan yang hendak di capai. Indikatorindikator yang di maksud meliputi:

1. Mengukur input
Input merupakan bagian yang penting dalam mendisain pengawasan agar mendapatkan hasil dari pengawasan.

2. Hasil langkah-langkah

Langkah-langkah awal pada dasarnya adalah pengadaan sarana untuk mengumpulkan informasi.

3. Gejala-gejala

Gejala-gejala dalam arti bahwa pelaksanaan pengawasan harus menemukan fakta-fakta tentang bagaimana tugas-tugas di jalankan dalam organisasi.

4. Perubahan dalam kondisi yang diasumsi.

\section{Kinerja}

Sementara itu, pengertian performance sering diartikan sebagai kinerja, hasil kerja atau prestasi kerja. Kinerja mempunyai makna lebih luas bukan hanya menyatakan sebagai hasil kerja, tetapi juga bagaimana proses kerja berlangsung. Kinerja adalah tentang melakukan pekerjaan dan hasil yang di capai dari pekerjaan tersebut. Kinerja adalah tentang apa yang dikerjakan dan bagaimana mengerjakanya. Kinerja merupakan hasil pekerjaan yang mempunyai hubungan kuat dengan tujuan strategis organisasi, Amstrong dan Baron dalam Wibowo (2010:2).

Wibowo (2010:47) kinerja merupakan kegiatan pengelolaan sumber daya organisasi untuk mencapai tujuan organisasi. Kinerja karyawan merupakan tanggung jawab setiap individu terhadap pekerjaan, membantu mendefinisikan harapan kinerja karyawan, mengusahakan kerangka kerja bagi supervisor dan pekerja saling berkomunikasi. Tujuan kinerja adalah menyesuaikan harapan kinerja individu dan tujuan organisasi kesesuaian antara upaya pencapaian tujuan individu dengan tujuan 
organisasi akan mampu mewujutkan kinerja yang baik.

Menurut Wilson (2012:230) peningkatan kinerja merupakan hal yang diinginkan dari pihak pemberi pekerja. Pemberi kerja meningkatkan kinerja karyawannya baik untuk kepentingan peningkatan hasil kerja dan keuntungan perusahaan. Di sisi lain, para pekerja berkepentingan untuk pengembangan diri dan promosi pekerjaan. Secara umum dapat dikatakan bahwa kinerja karyawan yang baik bertujuan untuk menigkatkan produktivitas. Oleh karena itu, perbaikan sistem kerja dilakukan setiap komponen yang ada dalam perusahaan.

Sistem manajemen kinerja karyawan (performance management system) merupakan proses untuk mengidentifikasi, mengukur dan mengevaluasi kinerja karyawan dalam perusahaan. Perusahaan perlu menerapkan sistem manajemen kinerja karyawan yang baik agar para karyawan merasa adil dan nyaman dalam melaksanakan pekerjaanya.

$$
\text { Menurut Wilson (2012:231) }
$$

penilaian kinerja karyawan adalah proses yang di lakukan organisasi untuk mengevaluasi atau penilaian keberhasilan karyawan dalam melaksanakan tugasnya. Penilaian dapat di lakukan dengan membandingkan hasil kerja yang di capai karyawan dengan standar pekerjaan. Bila hasil kerja yang diperoleh sampai atau melebihi standar pekerjaan dapat dikatakan kinerja seorang karyawan termasuk pada kategori baik. demikian sebaliknya seorang karyawan yang hasil pekerjaan tidak mencapai standar pekerjaan termasuk pada kinerja yang tidak baik atau berkinerja rendah.

Kinerja seorang karyawan dapat dipengaruhi berbagai faktor, baik faktor eksternal maupun internal dari karyawan tersebut. Simamora dalam Mangkunegara (2012:14) mengatakan bahwa kinerja pada umumnya dipengaruhi oleh tiga faktor yaitu:

A. Faktor individual yang terdiri dari:
1. Kemampuan dan keahlian
2. Latar belakang
3. Demografi

B. Faktor pisikologis yang terdiri dari:
1. Persepsi
2. Attitude
3. Personality
4.Pembelajaran
5.Motivasi

C. Faktor organisasi yang terdiri dari:

1. Sumber daya

2. Kepemimpinan

3. Penghargaan

4. Struktur

5. Job Design.

Menurut

Mangkunegara

(2011:16) kegunaan penilaian prestasi kerja (kinerja) karyawan adalah :

a. Sebagai dasar dalam pengambilan keputusan yang digunakan untuk prestasi, pemberhentian dan besarnya balas jasa.

b. Untuk mengukur sejauh mana seorang karyawan dapat menyelesaikan pekerjaannya.

c. Sebagai dasar untuk mengevaluasi efektivitas seluruh kegiatan dalam perusahaan.

d. Sebagai dasar untuk mengevaluasi program latihan dan keefektifan jadwal kerja, metode kerja, struktur organisasi, gaya pengawasan, kondisi kerja dan pengawasan.

e. Sebagai indikator untuk menentukan kebutuhan akan latihan bagi karyawan yang berada di dalam organisasi.

f. Sebagai alat untuk meningkatkan motivasi kerja karyawan sehingga dicapai performance yang baik.

g. Sebagai alat untuk dapat melihat kekurangan atau kelemahan dan meningkatkan kemampuan karyawan selanjutnya. 
h. Sebagai kriteria menentukan, seleksi dan penempatan karyawan.

i. Sebagai alat untuk memperbaiki atau mengembangkan kecakapan karyawan.

j. Sebagai dasar untuk memperbaiki atau mengembangkan uraian tugas (job description)

Menurut Umam dalam

Mangkunegara (2011:101) mengemukakan bahwa hasil kinerja secara kualitas dan kuantitas yang dicapai oleh seseorang pegawai dalam melaksanakan tugasnya sesuai dengan tanggung jawab yang diberikan kepadanya. Kontribusi hasil penilaian merupakan suatu yang sangat bermanfaat bagi perencanaan kebijakan organisasi organisasi secara terperinci. Penilaian kinerja bagi organisasi adalah :
a. Penyesuaian- penyesuaian kompensasi

b. Perbaikan kinerja

c. Kebutuhan latihan dan pengembangan

d. Pengambilan keputusan dalam hal penempatan promosi, mutasi, pemecatan, dan perencanaan tenaga kerja

e. Untuk kepentingan penelitian karyawan

f. Membantu diagnosis terhadap kesalahan desain karyawan

Berdasarkan uraian di atas maka kinerja individual dapat diukur di mana pada tingkat individu ini berhubungan dengan pekerjaan, mengacu pada tanggung jawab utama. Bidang kegiatan utama atau tugas kunci yang merupakan bagian dari pekerjaan seseorang. Fokusnya kepada hasil yang diharapkan dapat dicapai seseorang dan bagaimana kontribusi mereka terhadap pencapaian target personil, tim, departemen dan instansi Dari teori diatas bahwa kinerja adalah hasil dari suatu proses yang di lakukan manusia yang memberikan kotribusi bagi percapaian tujuan-tujuan organisasi. Dengan demikian, kinerja adalah tentang melakukan pekerjaan dan hasil yang dicapai dari pekerjaan tersebut.

Berdasarkan batasan dan penjelasan tersebut, maka kinerja dapat diartikan suatu ukuran perbandingan, baik buruknya aktivitas organisasi melalui hasil-hasil yang dicapai (output) sesuai dengan tujuan organisasi. Intinya batasan maupun yang akan digunakan, penilaian individu selalu diartikan sebagai suatu proses yang sistematis, dimana atasan mengkaji dan menilai kemampuan, prilaku kerja dan hasil kerja karyawan dalam suatu periode tertentu untuk digunakan sebagai bahan pertimbangan bagi pengambilan keputusan tentang tindakan-tindakan dibidang sumber daya manusia.

Moeheriono

(2010:63)

menjelaskan bahwa dalam suatu organisasi dikenal tiga jenis kinerja yang dapat dibedakan, yaitu sebagai berikut:

1. Kinerja operasional (operation performance) kinerja ini berkaitan dengan efektivitas penggunaan setiap sumber daya yang digunakan oleh perusahaan, seperti modal, bahan baku, teknologi dan lain sebagainya.

2. Kinerja administrasi (administratif performance) kinerja ini berkaitan dengan kinerja administrasi organisasi, termasuk didalamnya struktur administratif yang mengatur hubungan otoritas wewenang dan tanggung jawab dari orang yang menduduki jabatan. Selain itu, berkaitan dengan kinerja mekanisme aliran informasi antarunit kerja dalam organisasi.

3. Kinerja strategik (strategic performance) kinerja ini berkaitan 
atas kinerja perusahaan dievaluasi ketepatan perusahaan dalam memilih lingkungannya dan kemampuan adaptasi perusahaan, khususnya secara strategi perusahaan dalam menjalankan visi dan misinya. Sehingga dengan keberhasilan kinerja strategik, perusahaan bisa mencapai keunggulan bersaingnya. Dan bisa menjadi perusahaan yang menjadi contoh bagi perusahaan pesaing lainnya.

Menurut Wibowo (2010:102) menyatakan bahwa indikator kinerja antara lain sebagai berikut :

1. Tujuan

Tujuan merupakan keadaan yang berbeda yang secara aktif dicari oleh seorang individu atau organisasi untuk dicapai.

2. Standar

Standar mempunyai arti penting karena memberitahukan kapan suatu tujuan dapat diselesaikan. Standar merupakan suatu ukuran apakah tujuan yang diinginkan dapat tercapai.

3. Umpan Balik

Umpan balik melaporkan kemajuan, baik kualitas maupun kuantitas, dalan mencapai tujuan yang didefinisikan oleh standar. Umpan balik terutama penting ketika kita mempertimbangkan "real goals" atau tujuan sebenarnya.

4. Alat atau Sarana

Alat atau sarana merupakan sumber daya yang dapat dipergunakan untuk membantu menyelesaikan tujuan dengan sukses. Alat atau sarana merupakan faktor penunjang untuk mencapai tujuan. Tanpa alat dan sarana, tugas pekerjaan spesifik tidak dapat dilakukan dan tujuan tidak dapat diselesaikan sebagaimana harusnya.
5. Kompetensi

Kompetensi merupakan kemampuan yang dimiliki seseorang untuk menjalankan pekerjaan yang diberikan kepadanya dengan baik. Kompetensi memungkinkan seseorang mewujudkan tugas yang berkaitan dengan pekerjaan yang diperlukan untuk mencapai tujuan.

Berdasarkan uraian kajian teoritis tersebut diatas dapat dikemukakan hipotesis statistik sebagai berikut:

Ho : Tidak terdapat pengaruh pengawasan terhadap kinerja karyawan pada CV. Havraco Jaya Palembang

$\mathrm{Ha}$ : Ada pengaruh pengawasan terhadap kinerja karyawan pada CV. Havraco Jaya Palembang

\section{Metode Penelitian}

Variabel-variabel yang digunakan dalam penelitian ini adalah sebagai berikut :

a. Variabel bebas (independen) yaitu pengawasan $(\mathrm{X})$

b. Variabel terikat (dependen) yaitu Kinerja (Y)

Menurut Sugiyono (2014:115) populasi adalah wilayah generalisasi yang terdiri atas objek/subjek yang merupakan kuantitas dan karakteristik tertentu yang ditetapkan oleh peneliti untuk dipelajari dan kemudian ditarik kesimpulannya. Populasi dalam penelitian ini sebanyak 30 orang karyawan CV. Havraco Jaya Palembang. Sedangkan menurut Arikunto (2010:174) sampel adalah sebagian atau wakil populasi yang diteliti. Pada penelitian ini yang dijadikan sampel adalah sebanyak 30 orang. 
Menurut Sugiyono (2014:24) metode penelitian survei adalah metode penelitian kuantitatif yang digunakan untuk mendapatkan data yang terjadi pada masa lampau atau saat ini. Tentang keyakinan, pendapat, karakteristik, perilaku, hubungan variabel dan untuk menguji beberapa hipotesis tentang variabel sosiologis dan pisikologis dari sempel yang di ambil dari populasi tertentu, tehnik pengumpulan data dengan (dokumentasi dan kuesioner) dan hasil penelitian cenderung untuk digeneralisasikan.

Teknik pengumpulan data pada penelitian ini dilakukan dengan cara sebagai berikut:

a. Kuesioner merupakan teknik pengumpulan data yang dilakukan dengan cara memberi seperangkat pertanyaan kepada responden untuk dijawab.

b. Dokumentasi ditujukan untuk memperoleh data langsung dari tempat penelitian, meliputi yang relevan, peraturan-peraturan, laporan kegiatan, foto-foto film dokumentar, data yang relevan penelitan.

Pengumpulan data dilakukan dengan menggunakan kuesioner sehingga kesahihan dan keaslian suatu hasil penelitian sosial sangat ditentukan oleh alat ukur yang digunakan, apabila alat ukur yang digunakan tidak valid atau tidak dapat dipercaya maka hasil penelitian yang dapat diperoleh tidak akan menggambarkan kaadaan yang sesungguhnya. Untuk mengatasi hal itu diperlukan dua macam pengujian yaitu, validitas dan reliabilitas. Pengujian instrumen dalam penelitian ini menggunakan bantuan SPSS versi 20.

Hasil penelitian yang valid bila terdapat kesamaan antara data yang terkumpul dengan data yang sesungguhnya terjadi pada objek yang di teliti. Instrument yang valid berarti alat ukur yang di gunakan untuk mendapatkan data valid. Valid berarti instrument tersebut dapat di gunakan untuk mengukur apa yang sebenarnya di ukur. Dalam pengujian validitas menggunakan rumus korelasi sebagai berikut. Menurut Sugiyono (2014:172)

$r_{\mathrm{xy}}=\frac{n \sum \mathrm{xy}-\left(\sum x\right)\left(\sum \mathrm{y}\right)}{\sqrt{\left\{n \sum x^{2}-\left(\sum x^{2}\right)\right\}\left\{n \sum y^{2}-\left(\sum y\right)^{2}\right\}}}$

Di mana :

$r_{x y}=$ Koefisien korelasi validitas

$\mathrm{x}=$ Skor butir

$\mathrm{y} \quad=$ Skor total

$x^{2} \quad=$ Kuadrat skor butir

$y^{2}=$ Kuadrat skor butir

$n \quad=$ Jumlah responden

Analisis di lakukan terhadap semua butir instrument. Kriteria pengujiannya di lakukan dengan cara membandingkan $r$ hitung dengan $r_{\text {table }}$ pada taraf $a=0,05$ jika hasil perhitungan ternyata $r_{\text {hitung }}>r_{\text {table }}$ maka butir instrument di anggap valid, sebaliknya jika $r_{\text {hitung }}<r_{\text {table }}$ maka tidak valid, sehingga instrument tidak dapat di gunakan dalam penelitian.

Reliabilitas merupakan indeks yang menunjukkan sejauh mana suatu alat pengukur dapat di percaya atau dapat di andalkan. Uji reliabilitas yang di gunakan dengan teknik belah dua dari. Spearman brown (split Half), yaitu : Menurut Sugiyono (2014 : 258)

$r_{i=\frac{2 r_{b}}{1+r_{b}}}$

Di mana :

$r_{i}=$ Reliabilitas internal seluruh instument

$r_{b}=$ Nilai koefesiensi korelasi yang di sebutkan sebagai indeks korelasi antara dua belahan instrument 


\section{Analisis Regresi Liniear Sederhana \\ Menurut Riduwan (2012:147)} regresi linear sederhana adalah suatu proses memperkirakan secara sistematis tentang apa yang paling mungkin terjadi di masa yang akan datang berdasarkan informasi masa lalu dan sekarang yang dimiliki agar kesalahannya dapat di perkecil. Kegunaan regresi dalam penelitian salah satunya adalah untuk meramalkan atau memprediksi variable terikat $(Y)$ dan variabel bebas $(\mathrm{X})$ diketahui. Dengan persamaan regresi sebagai berikut: Riduwan (2012:148).

$\hat{Y}=a+b X$

$b=\frac{n \sum X Y-\left(\sum X\right)(\Sigma Y)}{n \cdot \sum X^{2}-\left(\sum X\right)}$

$a=\frac{\left(\sum y\right)\left(\sum x\right)\left(\sum y\right)}{n \sum x^{2}-\left(\sum x\right)}$

Keterangan :

$X$ : Variabel Pengawasan

$Y:$ Variabel Kinerja

$a$ : Konstanta

$b$ : Koefisien regresi

$\mathrm{n}$ : Jumlah responden

\section{Analisis Koefisien Korelasi Sedehana}

Menurut Sugiyono (2014: 230) korelasi sederhana adalah merupakan yang menunjukkan arah hubungan dua variabel. Korelasi dapat dirumuskan :

$r_{\mathrm{xy}}=\frac{n \sum \mathrm{xy}-\left(\sum x\right)\left(\sum \mathrm{y}\right)}{\sqrt{\left\{n \sum x^{2}-\left(\sum x^{2}\right)\right\}\left\{n \sum y^{2}-\left(\sum y\right)^{2}\right\}}}$

Keterangan :

$\underline{r_{x y}}:$ Korelasi antara variabel $X$ dan $Y$

$X$ : Nilai variabel bebas yaitu pengawasan

y : Nilai variabel tidak bebas yaitu kinerja karyawan

$\mathrm{n}$ : Jumlah data

$\Sigma$ : Jumlah keseluruhan
Untuk dapat memberikan penafsiran terhadap koefisien korelasi yang ditemukan tersebut, maka dapat digunakan ketentuan yang tertera pada tabel 1 sebagai berikut :

Tabel 1

Interprestasi terhadap Koefisien Korelasi

\begin{tabular}{|c|c|}
\hline $\begin{array}{c}\text { Interval } \\
\text { Koevisien }\end{array}$ & $\begin{array}{c}\text { Tingkat } \\
\text { Hubungan }\end{array}$ \\
\hline $0,00-0,199$ & Sangat rendah \\
$0,20-0,399$ & Rendah \\
$0,40-0,599$ & Sedang \\
$0,60-0,799$ & Kuat \\
$0,80-1,000$ & Sangat kuat \\
\hline \multicolumn{2}{|c|}{ Sumber :Sugiyono, (2014:231) }
\end{tabular}

\section{Koefisien Determinasi}

Koefisien Determinasi adalah kuadrat dari koefisien korelasi $\left(r^{2}\right)$ koefisiensi ini disebut koefisien penentu karena varians yang terjadi pada variabel dependen dapat di jelaskan melalui varians yang terjadi pada variabel independent. Menurut Sugiyono, (2014:232)

$\mathrm{R}=\left(\mathrm{r}^{2}\right) \times 100 \%$

Di mana :

$\mathrm{R}=$ Koefesiensi determinasi

$r=$ Koefesiensi korelasi variabel bebas dan variabel terikat

\section{Analisis Uji t}

Riduwan (2012:160) uji $t$ dilakukan untuk mengetahui ada tidaknya pengaruh yang signifikan antara dua variabel. Mengikuti fungsi $t$ dengan derajat kebebasan (n-2) rumus yang digunakan adalah sebagai berikut. Supranto (2013: 347)

$t_{\text {hitung }}=\frac{b}{S b}$

keterangan :

$\underline{t}$ : thitung yang selanjutnya dibandingkan dengan tabel

$b$ : Koefisien regresi

$S_{b}$ : Simpangan baku koefisien regresi 
$S_{e}:$ Standar error

Keriteria Pengujian :

Bila tabel $>$ thitung berarti diterima $\mathrm{H}_{\mathrm{o}}$, tolak $\mathrm{H}_{\mathrm{a}}$

Bila tabel < thitung berarti ditolak $\mathrm{H}_{0}$ diterima $\mathrm{H}_{\mathrm{a}}$

\section{Hasil dan Pembahasan Penelitian}

Data yang digunakan dalam penelitian ini adalah data primer, yaitu data yang diperoleh secara langsung dari objek penelitian. dengan menggunakan data kuesioner yang dibagi kepada 30 orang responden yang bertindak sebagai sampel. Dari data penelitian ini terdiri dari 2 (Dua) variabel yaitu pengawasan $(X)$ dan kinerja karyawan $(\mathrm{Y})$.

Untuk keperluan analisis

dilakukan pengumpulan data dengan memberikan kuesioner kepada karyawan CV. Havraco Jaya Palembang. Kuesioner diberikan kepada karyawan sebanyak 30 orang. Penelitian ini bertujuan untuk mengetahui pengaruh pengawasan terhadap kinerja karyawan pada CV. Havraco Jaya Palembang. Penelitian ini dilakukan dengan cara menggunakan analisis korelasi dan regresi, namun sebelumnya terlebih dahulu peneliti melakukan uji coba instrumen penelitian (kuesioner) untuk menyatakan validitas dan reabilitas.

Oleh karenanya, sebelum instrumen itu digunakan maka terlebih dahulu harus dilakukan uji validitas dan reliabilitas tujuanya adalah agar data yang di ambil valid yakni benarbenar mengukur apa yang hendak di ukur. Kemudian instrumen itu harus reliabel, artinya (konstan) di dalam pengambilan data. Uji validitas dan reliabilitas adalah untuk mengetahui apakah instrumen penelitian yang menjadi alat ukur valid atau dapat di percaya.

Ketentuan untuk uji validitas adalah membandingkan nilai rhitung dengan $r_{\text {tabel, }}$ rtabel dapat di cari pada signifikansi 0,05 dengan uji 2 sisi dan jumlah data $(n)=30$, maka didapat $r_{\text {tabel }}$ sebesar 0,361 (lihat pada tabel $r$ ). Apabila $r_{\text {hitung }}>r_{\text {tabel }}$ maka butir atau variabel yang diteliti adalah valid. Pengujian validitas dan reliabilitas di lakukan pada karyawan CV. Havraco Jaya Palembang yang berjumlah 30 karyawan dengan hasil semua kuisioner pada variabel Pengawasan (X) diperoleh hasil bahwa nilai $r_{\text {hitung }}$ lebih besar dari pada nilai $r_{\text {tabel }}$ sehingga keseluruhan item pertanyaan yang ada pada instrumen tersebut dapat dijadikan sebagai alat ukur yang valid dalam analisis selanjutnya. Sedangkan pada variabel Kinerja Karyawan (Y) diperoleh hasil bahwa nilai $r_{\text {hitung }}$ seluruh kuisioner lebih besar dari pada nilai $r_{\text {tabel }}$ sehingga keseluruhan item pertanyaan yang ada pada instrumen tersebut dapat dijadikan sebagai alat ukur yang valid dalam analisis selanjutnya.

Menurut Priyanto (2013:30) suatu alat pengukur dikatakan reliabel bila alat itu dalam mengukur gejala pada waktu berlainan senantiasa menunjukkan hasil yang sama dan diukur dengan uji statistik cronbach's alpha $(\alpha)$ lebih dari 0,6. Suatu variabel dikatakan reliabel jika memberikan nilai cronbach's alpha > 0,6 maka item tersebut dinyatakan reliabel. Dari hasil perhitungan dengan SPSS 20 diperoleh hasil bahwa nilai variabel pengawasan yang dihitung dengan Cronbanch's Alpa sebesar 0,758 >0.6 Karena nilai diatas 0,6 maka dapat disimpulkan bahwa alat ukur dalam penelitian ini realiabel dan dapat dijadikan alat ukur dianalisis selanjutnya. Sedangkan nilai variabel kinerja yang dihitung dengan cronbach' alpha sebesar 0,847 > 0,6. Karena nilai diatas 0,6 maka dapat di simpulkan bahwa alat ukur dalam 
penelitian ini realiabel dan dapat dijadikan alat ukur.

\section{Analisis Regresi Linier Sederhana}

Analisis regresi linier sederhana dengan menggunakan bantuan program SPSS 20 yang hasilnya dapat dilihat pada tabel berikut :

Tabel 2

Hasil Regresi Linier Sederhana

Coefficients $^{a}$

\begin{tabular}{|c|c|c|c|c|c|}
\hline \multirow[b]{2}{*}{ Model } & \multicolumn{2}{|c|}{$\begin{array}{c}\text { Unstandardized } \\
\text { Coefficients }\end{array}$} & \multirow{2}{*}{\begin{tabular}{|c|}
$\begin{array}{c}\text { Standardized } \\
\text { Coefficients }\end{array}$ \\
Beta \\
\end{tabular}} & \multirow[b]{2}{*}{$\mathrm{T}$} & \multirow[b]{2}{*}{ Sig. } \\
\hline & $\mathrm{B}$ & Std. Error & & & \\
\hline $\begin{array}{ll}1 & \text { (Constant) } \\
& \text { Pengawasan_X }\end{array}$ & $\begin{array}{r}18,975 \\
, 745\end{array}$ & $\begin{array}{r}4,553 \\
, 141\end{array}$ & ,255, & $\begin{array}{l}5,638 \\
3,229\end{array}$ & .0 \\
\hline
\end{tabular}

a. Dependent Variable: Kinerja_Y

Sumber : Output SPSS for Windows 20, 2015

Dari hasil perhitungan dengan SPSS 20 diperoleh persamaan regresi

$$
Y=a+b X
$$$$
Y=18,975+0,745 X
$$

Konstanta sebesar 18,975 artinya jika pengawasan $(X)$ nilainya adalah 0 , maka kinerja karyawan $(\mathrm{Y})$ nilainya sebesar 18,975 sedangkan koefisien b sebesar 0,745 artinya setiap perubahan 1 (satu) unit variabel pengawasan akan menyebabkan peningkatan nilai $\mathrm{Y}$ atau variabel kinerja sebesar 0,745.

\section{Analisis Korelasi (R)}

Analisis korelasi dengan menggunakan bantuan program SPSS 20 yang hasilnya dapat dilihat pada tabel berikut.

Tabel 3

Uji Korelasi (R)

Model Summaryb

\begin{tabular}{|l|r|r|r|r|}
\hline Model & $\mathrm{R}$ & R Square & \multicolumn{1}{|c|}{$\begin{array}{c}\text { Adjusted R } \\
\text { Square }\end{array}$} & $\begin{array}{c}\text { Std. Error of the } \\
\text { Estimate }\end{array}$ \\
\hline 1 &, $521^{\mathrm{a}}$ &, 271 &, 054 & 4,727 \\
\hline
\end{tabular}

a. Predictors: (Constant), Pengawasan_X

b. Dependent Variable: Kinerja_Y

Sumber : Output SPSS for Windows 20, 2015

Dari tabel diatas, dapat dilihat bahwa korelasi (R) antara pengawasan $(X)$ terhadap kinerja karyawan $(Y)$ sebesar 0,521. Hal tersebut berarti bahwa hubungan pengawasan $(X)$ dengan kinerja karyawan $(\mathrm{Y})$ adalah sedang.

\section{Analisis Koefisien Determinasi (R Square) \\ Analisis koefisien Determinasi} dengan menggunakan bantuan program SPSS 20 yang hasilnya dapat dilihat pada tabel berikut. 
Tabel 4

Uji Determinasi (R Square)

Model Summaryb

\begin{tabular}{|l|r|r|r|r|}
\hline Model & $\mathrm{R}$ & $\mathrm{R}$ Square & $\begin{array}{c}\text { Adjusted R } \\
\text { Square }\end{array}$ & $\begin{array}{c}\text { Std. Error of the } \\
\text { Estimate }\end{array}$ \\
\hline 1 &, $521^{\mathrm{a}}$ &, 271 &, 054 & 4,727 \\
\hline
\end{tabular}

a. Predictors: (Constant), Pengawasan_X

b. Dependent Variable: Kinerja_Y

Sumber : Output SPSS for Windows 20, 2015

Kajian dimana (R Square) $27,1 \%$. Artinya variabel kinerja karyawan dijelaskan oleh variabel pengawasan sebesar $27,1 \%$ dan sisanya $72,9 \%$ dipengaruhi oleh faktorfaktor lain yang tidak diteliti dalam penelitian ini.

\section{Analisis uji $t$}

Tabel berikut menyajikan hasil uji $t$ yang merupakan pengujian hipotesis dalam penelitian ini. Penelitian dilakukan dengan bantuan SPSS 20

Tabel 5

Uji t

Coefficients $^{a}$

\begin{tabular}{|c|c|c|c|c|c|}
\hline \multirow[b]{2}{*}{ Model } & \multicolumn{2}{|c|}{$\begin{array}{l}\text { Unstandardized } \\
\text { Coefficients }\end{array}$} & \multirow{2}{*}{$\begin{array}{c}\begin{array}{c}\text { Standardized } \\
\text { Coefficients }\end{array} \\
\text { Beta }\end{array}$} & \multirow[b]{2}{*}{$\mathrm{T}$} & \multirow[b]{2}{*}{ Sig. } \\
\hline & $B$ & Std. Error & & & \\
\hline (Constant) & 18,975 & 4,553 & & 5,638 &, 000 \\
\hline Pengawasan_X & 745 & 141 & 255 & 3,229 & ,018 \\
\hline
\end{tabular}

a. Dependent Variable: Kinerja_Y

Sumber : Output SPSS for Windows 20, 2015

Uji hipotesis dilakukan dengan langkah-langkah sebagai berikut:

1. Menentukan Hipotesis

$\mathrm{H}_{0}$ : Tidak terdapat pengaruh antara pengawasan terhadap kinerja karyawan

$\mathrm{H}_{\mathrm{a}}$ : Terdapat pengaruh antara pengawasan terhadap kinerja karyawan

2. Menentukan tingkat signifikansi

Tingkat signifikansi mengunakan alpha 5\%.

3. Menentukan $t_{\text {tabel }}$

Tabel distribusi $t$ dicari pada alpha $=$ $5 \%$ (uji 1 sisi) dengan derajat kebebasan (DF) n-k-1 atau 30-1-1 = 28 ( $\mathrm{n}$ adalah jumlah kasus dan $\mathrm{k}$ adalah jumlah variabel independen). Hasil diperoleh untuk $t_{\text {tabel }} \quad 0,05 / 2$ sebesar 2,048.

4. Apabila $t_{\text {hitung }}>t_{\text {tabel }}$ maka $H_{a}$ diterima $H_{o}$ ditolak

Artinya Terdapat pengaruh pengawasan terhadap kinerja karyawan.

5. Apabila $t_{\text {hitung }}<t_{\text {tabel }}$ maka $H_{o}$ diterima $H_{a}$ ditolak

Artinya tidak terdapat pengaruh pengawasan terhadap kinerja karyawan.

6. Membandingkan $t_{\text {hitung }}$ dengan $t_{\text {tabel }}$

Nilai $t_{\text {hitung }}>t_{\text {tabel }}(3,229>2,048)$ maka $\mathrm{H}_{\mathrm{a}}$ diterima dan $\mathrm{H}_{\mathrm{o}}$ ditolak 
artinya Terdapat pengaruh pengawasan terhadap kinerja karyawan pada CV. Havraco Jaya Palembang.

E. Kesimpulan dan Saran Sesuai dengan hasil dan pembahasan penelitian, maka dapat disimpulkan:

1) Persamaan regresi linier sederhana $Y=18,975+0,745 X$ artinya jika pengawasan $(X)$ nilainya adalah 0 , maka kinerja karyawan (Y) nilainya sebesar 18,975. Sedangkan setiap perubahan 1 (satu) unit nilai $X$ atau variabel pengawasan akan menyebabkan peningkatan nilai $\mathrm{Y}$ atau variabel kinerja sebesar 0,745.

2) Diperoleh nilai korelasi $(R)$ sebesar 0,521 yang berarti bahwa hubungan pengawasan dan kinerja adalah sedang. Selain itu juga diperoleh nilai Koefisien Determinasi sebesar $27,1 \%$ hal ini menjelaskan bahwa variabel kinerja dijelaskan oleh pengawasan sebesar $27,1 \%$ dan sisanya $72,9 \%$ dijelaskan oleh faktor-faktor lain yang tidak diteliti dalam penelitian ini.

3) Berdasarkan nilai thitung yang lebih besar dari nilai tabel $(3,229>2,048)$ maka tolak hipotesis nol $\left(\mathrm{H}_{\mathrm{o}}\right)$ dan menerima hipotesis alternative $\left(\mathrm{H}_{\mathrm{a}}\right)$ yaitu terdapat pengaruh pengawasan terhadap kinerja karyawan pada CV. Havraco Jaya Palembang.

Berdasarkan hasil penelitian tersebut diatas, penulis menyarankan kepada manajemen perusahaan untuk terus semakin meningkatkan pengawasan sehingga diharapkan akan terus dapat meningkatkan kinerja karyawan.
DAFTAR PUSTAKA

Arikunto, Suharsimi. 2010. Prosedur Penelitian Suatu Pendekatan Praktik. Jakarta : PT. Rineka Cipta.

Mangkunegara, Anwar Prabu. 2011. Evaluasi Kinerja Sumber Daya Manusia. Cetakan keenam. Bandung: Rafika Aditama.

Moekijat. 2010. Manajemen Sumber Daya Manusia. Bandung : Mandar Maju.

Moeheriono. 2010. Pengukuran Kinerja Berbasis Kompetensi. Jakarta : Ghalia Indonesia.

Riduwan. 2012. Belajar Mudah Penelitian Untuk Guru Karyawan dan Peneliti Pemula. Bandung : Penerbit Alfabeta.

Setyowati. 2013. Organisasi Dan kepemimpinan Modern. Yogyakarta : Ruko Jambusari.

Sugiyono. 2014. Skripsi, Tesis, Dan Disertasi. Bandung : Alfabeta.

Sukarman. 2011. Dasar-Dasar Manajemen. Bandung : Sumber Resik.

Supranto, J. 2013. Standar Teori dan Aplikasi. Jakarta : Erlangga.

Priyatno, Duwi. 2010. Paham Analisis Statistik Data Dengan SPSS. Yogyakarta: MediaKom.

Wibowo. 2010. Manajemen Kinerja. Jakarta : PT. Raja Grafindo Persada.

Wilson, Bangun. 2012. Manajemen Sumber daya Manusia. Bandung : Erlangga dengan Power Macpro. 